\title{
Asset-Building and Microfinance: An Econometric Analysis
}

\author{
Stephen Mago \\ Department of Development Studies, University of Fort Hare, P. Bag X1314,Alice, South Africa. \\ Cell: 0846969043.E-mail: smago@ufh.ac.za or stepmago@gmail.com \\ Shamiso Mago \\ Department of Development Studies, University of Fort Hare, P. Bag X1314,Alice, South Africa.
}

\section{Doi:10.5901/mjss.2013.v4n3p449}

\begin{abstract}
The poor's central resources for livelihoods enhancement are their assets. This emphasizes the need for asset strengthening and accumulation to achieve social transformation and poverty reduction. Poor people rarely speak of income but the management of assets in the form of physical, human, social and environmental as a way to cope with their vulnerability. This paper attempts to carry out an econometric analysis of the how asset-building can be enhanced by the provision of microfinance. The poor have lower assets thus they are disadvantaged by financial exclusion. Results show a statistically positive relationship between microfinance and assets.
\end{abstract}

Keywords: Assets, Asset-building, Microfinance, livelihoods

\section{Introduction and Background}

The poor's central resources for livelihoods enhancement are their assets. This emphasizes the need for asset accumulation to achieve poverty alleviation and reduction. According to Narayan et al., (2000) in Adjei et al. (2009), in Ghana the poor rarely speak of income but the management of assets in the form of physical, human, social (including political) and environmental as a way to cope with their vulnerability. The poor have lower assets and this impacts negatively on them because they are then excluded from the financial system. This is why they can hardly access financial resources from the traditional financial sector, they are actually marginalized. Assets are used by traditional financial institutions as physical collateral security. They safeguard loans taken by individuals, households or organizations. The absence of assets among the poor makes it tough for them to access credit. Adjei et al., (2009) argue that microfinance can provide a number of pathways to reduce vulnerability among poor people. These include the strengthening, and building of assets. Vulnerability is then reduced through sale of assets for consumption smoothing and to react to emergencies such as sickness or death(s) in the family. Zhan and Sherraden (2003) describe the importance of assets as follows:

\begin{abstract}
"Assets are important because they can bring security, especially in times of hardship or economic stress, such as unemployment, illness, or family breakup. Assets also increase power and control: "Most people use income for day-today necessities; by contrast, assets often bring income, power, and independence" (Oliver and Shapiro 1995, p.32). Command over resources can change the way people think and can expand an array of available opportunities. Assets can provide a stake and position in society. Assets may have a wide range of positive personal and social effects on wellbeing beyond consumption. These effects may include greater future orientation, development of other assets, improved household stability, greater focus and specialization, a foundation for risk-taking, increased personal efficacy, increased social influence, increased political participation, and enhanced welfare of offspring". (Zhan and Sherraden, 2003:193)
\end{abstract}

Zhan and Sherraden summarize the efficacy of asset holding by households. Of particular note is the importance of assets accumulation over other activities aimed at poverty alleviation. The poor in rural communities have a variety of assets that need to be mobilized. In other words, the poor may not be aware of the resources that surround them hence they remain in poverty. Sherraden (1991:6) asserts that "With assets, people begin to think in the long term and pursue long-term goals. In other words, while income feeds the people's stomachs, assets change their heads". Therefore, this supports the need for assets as a means for poverty alleviation in rural communities. Sherraden further argues that asset accumulation plays a critical role in economic and social well-being. Furthermore, Fay (2005:195) notes that assets are at 
the core of households' survival strategies. Assets help the poor to meet their needs in future, enhance wealth improvement and reduce exposure to external shocks. They also minimize the consequences of external shocks. The poor are excluded from the formal financial markets hence they accumulate their savings through semi-durable and durable assets. Assets accumulation is therefore made possible by allowing the poor to have access to financial resources (i.e. microfinance). Matin et al. (1999) in Fay (2005) state that the following changes (in terms of asset position of the poor) are induced by improved access to financial resources:

- "A decline in the holding of assets with lower risk-adjusted returns,

- A shift away from assets held for pecuniary savings towards assets held for speculative purposes,

- A decline in the level of credit obtained at high cost (usually informal sources) and

- A decline in the frequency and amount of asset sales at low prices." (Fay, 2005:209).

Morgan and Ziglio (2007) call the mobilization of communities to use their assets around a vision and a plan to solve their own problems 'community assets mapping'. According to them, an assets approach can be used to identify distinct categories for asset identification. These are primary, secondary and potential building assets blocks. First, primary building blocks refer to assets that are located in the neighborhood and under the community's control. Secondly, secondary building blocks refer to assets located within the community but under the control of outsiders and lastly potential building blocks refer to assets originating from outside the neighborhood and under the control of outsiders. The study results show that the rural people have resources but what lacks is their link with livelihood strategies and this link needs to be developed.

Microfinance promotes asset-building among the poor by avoiding distress through unplanned sales of assets and replacement of existing productive assets destroyed in natural disasters (Adjei et al, 2009). Since assets are central to the livelihoods of the poor, microfinance should then enhance their accumulation so as to cushion the people during shocks.

\section{Objective of the Paper}

The objective of the paper is to establish how microfinance enhances asset-building for poverty alleviation. It is anticipated that the outcomes will contribute towards the development of innovative microfinance strategies that are meant to promote asset-building. To achieve the objective, the followed methodology was used.

\section{Methodology of the Paper}

This paper used a quantitative methodology. Data was collected from 250 microfinance participating and 250 nonparticipating rural household heads $(n=500)$ in Masvingo district of Zimbabwe. Questionnaires were administered to collect cross-sectional data. Questionnaires and interviews were used to collect data related to microfinance and poverty alleviation from the rural areas. The interviews were carried out with rural clients/participants (beneficiaries of rural microfinance poverty alleviation programs) and non-participants. Respondents were sampled using cluster sampling technique followed by simple random sampling.

The effect of microfinance is measured by calculating the differences between participants and non-participants. The study adopted the following model for use in the impact analysis: $Y_{i}=\alpha_{0}+X_{i j} \alpha_{1}+V_{j} \beta+M_{i j} \gamma+T_{i j} \delta+\eta_{i j}$. Where:

- Yij is a vector of outcome variables for household $i$ in village j, (i.e. Assets, income and savings)

- Xij captures household characteristics such as age, gender, education, marital status and household size.

- $\quad \mathrm{Vj}$ is a vector of village characteristics such as distance from the city, roads, communication facilities and electricity.

- Mij is a membership dummy variable equal to 1 for any household that participates (members) in the program and 0 for nonparticipants (non-members).

- Tij is the number of months that microfinance program was available to members in the village.

- $\eta$ ij is the error term. It captures other possible factors not specified.

- Subscripts $i$ and $j$ stand for individual respondent and village respectively; and

- The symbols $\alpha, \beta, y$ and $\delta$ are the coefficients to be estimated.

\footnotetext{
${ }^{1}$ Community asset mapping is a positive, realistic and inclusive process whereby the strengths of local communities are developed towards building assets for improving the wealth position of community members (see Morgan and Ziglio, 2007:20; Kretzmann and McKnight, 1993:5-6).
} 


\subsection{Assets Model}

Assets: $\log$ Assets $\left(Y_{i}\right)=a_{0}+X_{i j} \alpha_{1}+V_{j} \beta+M_{i j} Y+T_{i j} \delta+\eta_{i j}$.

The assets in the study entail livestock, farm implements, kitchen utensils, household items (furniture, television sets, and radios) and vehicles. Market values were used to calculate the aggregate values of assets.

SPSS was used to generate descriptive statistics. Household outcomes on assets were regressed against independent variables using PcGive software. The following subsections analyze the five assets/capitals in relation to microfinance for poverty alleviation.

\section{Conceptual and Theoretical Synopsis}

The notion of assets is based on the five capitals that form the basis of what the poor possess. These assets are also outlined in the Sustainable Livelihoods framework that outlines human, social, financial, physical and natural 'capitals'. The following section presents the assets or 'capitals'.

\subsection{Human Capital}

This refers to labor resources that households have. It represents the skills, knowledge, ability to labor and good health (DFID, 1999), that enable people to achieve positive livelihood outcomes. These have both quantitative and qualitative dimensions (Rakodi, 2002). The quality of household labor is improved through education and skills development and also the health status of household members. Empirical results on the impact of microfinance show that there is a positive relationship between microfinance participation and school going by children. In Bangladesh for instance Pitt and Khandker (1998) found that the number of school going children increased with participation in microfinance programs. On the other hand, they discovered that the number of girls going to school increased when women participate in microfinance.

Many people regard ill-health or lack of education as core dimensions of poverty and thus overcoming these conditions improves livelihood strategies (DFID, 1999). Empirical studies show that microfinance has achieved in the area of improving health and supporting education for children. For example in Zimbabwe a study by the Population Council (2002) demonstrated the claim. The Interagency Coalition on AIDS and Development (ICAD) had also carried out a study in 2001 on HIVIAIDS and microfinance in Sub-Saharan Africa and concluded that microfinance has a role to play in the fight against HIVIAIDS. According to ICAD's report of 2001, microfinance contributes to strengthening households' safety nets. One of the areas in our study site had microfinance clients that were either affected or infected by the HIVIAIDs condition. However, the clients demonstrated success at a field day display of their acquired assets. In their case, microfinance helped the vulnerable group of the rural populace.

Human capital investment has long-term benefits and provides means for survival as children get employment and send remittances to their parents. Training that is provided to microfinance participants also makes them to develop relevant knowledge and skills. A link also exists between human and social capital.

\subsection{Social capital}

According to Rakodi (2002), social capital is defined as the rules, norms, obligations, reciprocity and trust embedded in social relations, social structures, and society's institutional arrangements, which enable its members to achieve their individual and community objectives. Social interaction needs to be strengthened through persistent relations. Sa-Dhan (2003) and DFID (1999) define social capital as social resources (networks and connectedness, social claims, social relations, affiliations, associations) upon which people draw when pursuing different livelihood strategies requiring coordinated actions ( see also Vermaak, 2009). Rakodi (2002) notes that social capital may breakdown because of repeated shocks (such as drought) and economic crisis or physical insecurity (such as violence and crime).

In Zimbabwe, the crisis period (2000 to 2009) made social capital to breakdown since there was political violence that destroyed the existing social fabric in the rural areas. However, in some areas there was an improvement in social capital due to the crisis as people were sharing foodstuffs for the survival of all the members of the community. A close link exists between the two capitals (social and political capital). The latter is based on the access to the political process in decision-making. Political capital has an influence upon social capital and other household livelihood assets. 
When there is no economic crisis, the strength of the economy promotes the development of social capital. This means that access to microfinance is likely to cement social relations among community and household members. Microfinance participants usually work in groups, hence increasing collaboration and teamwork as part of the group dynamics. The Grameen Bank's group lending methodology takes advantage of social capital that allows peer pressure execution among group members. Instead of physical collateral security, poor borrowers use social collateral to secure loans from the bank.

Social capital is very important since it has a direct impact on other 'capitals'. DFID (1999) has clearly listed the advantages of social capital in the sustainable livelihoods framework as follows:

- $\quad$ "By improving the efficiency of economic relations, social capital can help increase people's incomes and rates of saving (financial capital) (isolated studies have shown that communities with 'higher levels' of social capital are wealthier-but questions remain about measuring social capital).

- Social capital can help to reduce the 'free rider' problems associated with public goods. This means that it can be effective in improving the management of common resources (natural capital) and maintenance of shared infrastructure (physical capital).

- Social networks facilitate innovation, the development of knowledge and sharing of that knowledge. There is therefore close relationship between social and human capital"(DFID,1999:9).

Strengthening of social capital in rural areas enables the creation of a social environment that is essential to people's well-being (Smets, 2006). Vermaak (2009) put forward that social capital contributes towards national building by bridging cultural diversities. Social capital is also very important because the Grameen Bank of Bangladesh used it to replace physical collateral security on loans. Peer pressure among group members was being used to enforce repayments. The idea of microfinance in this regard is a strong linkage that should be developed between microfinance and social capital. Another important aspect is physical capital.

\subsection{Physical capital}

Physical capital refers to productive and household assets that include tools, equipment, housing and other producer goods (DFID, 1999; Rakodi, 2002; Solebury, 2003; Moser and Dani, 2008). It also involves basic infrastructure such as transport, shelter, water, energy, communication, buildings, roads and dams (Rakodi, 2002). Access to physical capital helps people to have essentials for sustainable livelihoods. Rural micro-enterprises for instance need access to affordable transportation, secure shelter, adequate water supply and sanitation, affordable energy and communication (DFID, 1999). Rakodi further states that the ability to invest in production equipment may directly generate income and enhance labor productivity. There is an interaction among assets for sustainable livelihoods. Infrastructural development is important for health, social interaction and contributes to human and social capital development. In Bangladesh for example, the Grameen Bank financed poor and illiterate women in rural areas to start a telephone business. These women are popularly known as the 'telephone ladies'.

The "telephone ladies" were funded by the International Finance Corporation (IFC) through the Grameen Bank. Through the Grameen Telecom, the women operated cellular phones, charging villagers. Empirical studies (e.g. Narayan, 2002), indicate that $50 \%$ of the calls are made for economic and social reasons. According to Narayan, real savings were estimated between $\$ 2.70$ and $\$ 10.00$ made in place of travelling between villages and Dhaka. The project benefited both the villagers and local entrepreneurs.

As the microfinance expands, housing microfinance has emerged as a new concept in the field. Access to secure shelter and buildings is part of physical capital (DFID, 1999) that is a very important component of the livelihoods of the poor. This should be accompanied with adequate water supply and sanitation plus clean and affordable energy for sustainable livelihoods. According to DFID, a lack of housing and related facilities is considered to be a core dimension of poverty. A lack of access to decent shelter, clean water and energy lead to deterioration of human health. This will in turn affect people's productive capacities. Finance is also an important component in the continuum.

\subsection{Financial Capital}

Finance or economic capital refers to financial resources that are available to people which provide them with different livelihood options. These include cash, credit/debt, savings, remittances, pensions and other economic assets (Rakodi et al., 2002; Sa-Dhan, 2003). It is the domain of microfinance. DFID(1999) argues that the definition is not economically robust because it incorporates flows as well as stocks.

Financial resources are crucial for the pursuit of any livelihood strategy by the poor. To make the poverty 
alleviation agenda sustainable, microfinance services should focus at enhancing livelihoods among the poor. Promotional financial services refer to finance directed towards enhancing the livelihoods among poor people. Protective financial services include social security payments, donations and highly subsidized funds. These have an effect of 'killing' innovation among the poor. They make them passive actors in economic development. On the other hand, promotional finance makes the poor to be active as they work towards achieving their livelihood outcomes. The rural poor also benefit from natural capital-microfinance coupling.

\subsection{Natural capital}

This term is used to explain natural resource stocks, biodiversity and the environment. The components of natural capital include water, soil (land), air, and weather. Variations in the environment may pose challenges to the efforts of poor people to execute their coping strategies. DFID (1999) notes a very close relationship between the vulnerability context and natural capital. This is mainly because many shocks that destroy natural capital are processes of nature.

The ability to accumulate or access finance capital helps to smoothen consumption and cushion the poor against shocks (Rakodi, 2002). Microfinance then enables the poor to have access to financial resources hence improving their livelihood strategies in the event of shocks. According to Aheeyar (2006), microfinance was a handy intervention in the Tsunami-affected areas of Sri-Lanka. Microfinance enhanced the reactivation of livelihoods among the affected households and individuals in the affected areas. Beneficiaries of microfinance programs managed to accelerate the rebuilding process after the destruction. A study by HSRC, in 2002, shows that the cyclone Eline ${ }^{2}$ destroyed the livelihood base of poor people in the Chimanimani districts of Zimbabwe. Other areas like Masvingo province had isolated effects where livelihood strategies of the poor were disturbed. According to the HSRC study, the microfinance intervention was useful in restoring the capabilities of the poor people in the Chimanimani area.

Masvingo province (where the study area is located) is a drought prone region that falls in a low rainfall natural zone. Low rainfall conditions subdue the agricultural activities in the area. The province falls within the Natural regions III (7\%), IV (82\%) and V (11\%) which is generally dry. Rural areas depend on agriculture as the main economic activity but drought poses a very serious challenge to agricultural production. The strengthened linkage between capitals and microfinance can be viewed in three manifestations that positively affect asset-based livelihoods.

\section{Assets-Based Livelihoods and Microfinance}

The linkage between microfinance and the sustainable livelihoods (SL) should lead to what Moser and Dani (2008) ${ }^{3}$ refers to as asset accession, asset valorization and asset transformation. Assets accession means that the poor, due to microfinance, will have an increased access to assets. Assets valorization refers to the increase in the returns from assets that will help the poor to manage their livelihoods. Assets transformation then refers to microfinance activities that transform the status and value of assets.

The analysis of survey data established a positive and significant relationship between microfinance and assets. This implies that microfinance members have a potential to accumulate more assets than non-members so this could be enhanced by a microfinance-livelihoods linkage. The same was confirmed by Adjei et al. (2009a and 2009b) in their two Ghana studies. To achieve sustainable poverty alleviation, microfinance should then be positioned to address the challenges of inequality, inequity, imbalance in asset accumulation and macro-micro policy integration. Borrowing from Moser and Dani (2008), manifestations of incorporating microfinance into an asset-based framework can be developed (see Figure 6.3 below). Figure 1 below summarizes the manifestations of asset-based microfinance interventions.

\subsection{Asset Accession}

According to Moser and Dani (2008), asset accession is concerned about strengthening the poor's asset base. One of the strategies to promote this status is facilitation of loans through microfinance programs. The articulation between macro-level policies and micro-level policies benefits grassroots poverty alleviation efforts. Assets accession can then be achieved through the provision of microfinance services. This strengthens the link between microfinance and livelihoods among the poor. The linkage then strengthens resilience against external shocks to the poor's assets.

\footnotetext{
${ }^{2}$ Cyclone Eline was a devastating tropical storm that hit the east coast of Africa in 2000. Zimbabwe was also affected by the lesser but equally devastating effects of the storm.

${ }^{3}$ Moser and Dani (2008:30) used the concepts of asset accession, valorization and transformation in their explanation of Manifestations of AssetBased Social Policy. The same analogy was applied to microfinance in this study.
} 


\subsection{Assets valorization}

Valorization is concerned with interventions that improve the value or return on the poor's assets (Moser and Dani, 2008). This can be achieved through human capital investments, infrastructural developments, and social capital developments. Social inclusion is also an integral part of valorization and promotes livelihood improvements among the poor. Microfinance has an effect of injecting an essential resource for assets valorization efforts. Therefore, a linkage between microfinance and assets will strengthen the valorization of assets among the poor people.

Figure 1: Manifestations of Asset-Based Microfinance

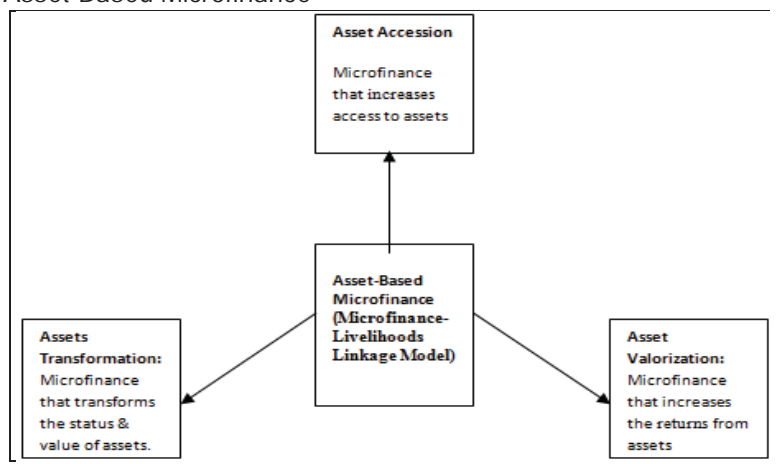

Source: Adapted from Moser and Dani (2008:30). Issues on microfinance were added by the author

\subsection{Assets Transformation}

It is important to ask whether microfinance intervention can have assets transformational effects. As indicated earlier, asset transformation refers to an improvement in the status and value of assets. For the poor to realize gains in assets accumulation there should be a transformational effect on their assets. Moser and Dani (2008) point out that assets transformation may involve removal of legal and institutional barriers that affect the poor's activities. From literature and research findings, this study found out that one of the objectives of rural microfinance is the creation of an enabling environment for poverty alleviation endeavors. Rural microfinance, if effectively coupled with livelihood assets, is likely to have a transformational effect on assets hence making the poor to achieve positive livelihood outcomes.

\section{Results}

\subsection{Microfinance and Asset Ownership}

The results of the asset function as shown in Table 1 below, suggest a robust model. Coefficients of the model have the expected signs which also conform to economic theory and augur well with other empirical work. The adjusted $\mathrm{R}^{2}$ of $9.5 \%$ (which is $10 \%$ to the nearest whole number), although low is not unexpected considering the cross sectional nature of the data. If the study was dealing with time-series data, a bigger $\mathrm{R}^{2}$ was likely to be realized. The $\mathrm{F}$ - value (4.495) also shows that the model is robust as explained by the global $p$-value of 0.000 . Figure 2 below shows that the estimated model tracks the actual data very well. The standard error of 1.74 is relatively small and also an indication that the estimated model is robust.

Table 1: Effects of Microfinance on Assets

Dependent variable: Log Assets

\begin{tabular}{lcccc}
\hline Independent variables & Coefficient & t-value & t-prob & Part. $R^{2}$ \\
Constant & 1.15832 & 1.09 & 0.276 & 0.0024 \\
Membership & 0.347925 & 2.17 & 0.031 & 0.0094 \\
Log Education & 0.488775 & 3.09 & 0.002 & 0.0189 \\
Log HH Size & 0.594123 & 3.05 & 0.002 & 0.0185 \\
Log Age & 1.23377 & 4.83 & 0.000 & 0.0450 \\
\hline
\end{tabular}

Key To Table 1: HH- Household.

Standard error $\quad 1.7401$ 


$\begin{array}{ll}\mathrm{R}^{2} & 0.0947 \\ \mathrm{~F}(4,495)= & 12.96[0.000]^{\text {* }} \\ \text { log-likelihood } & -983.927 \\ \text { mean(Log Assets) } & 7.4704 \\ \text { var (Log Assets) } & 3.3115 \\ \text { No. of observations } & 500\end{array}$

Source: Based on Author's Statistical Results.

Figure 2: Actual and Residual Estimates (of Assets)

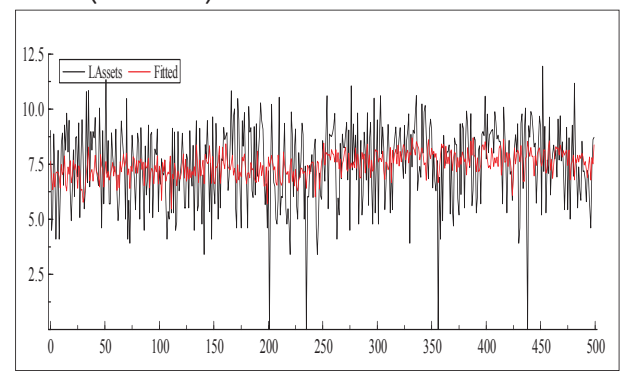

Source: Based on Author's Calculations.

Assets play a central role in poverty alleviation. An increase in assets means a decrease in poverty, that is, there is a negative relationship between asset ownership and poverty alleviation. Turning to the coefficient of interest, microfinance membership, our results suggest a positive relationship between microfinance membership and assets. The co-efficient is 0.3479 and is statistical significant at $5 \%$ (t-value of 2.17). This result suggests that microfinance members are about $35 \%$ better-off than non-members in terms of asset ownership. In other words, microfinance members are more likely to own more assets than non-members. This result implies that asset ownership reduces poverty. Individuals or households use assets to cushion themselves against shocks, hence reducing vulnerability. Asset ownership implies a better standard of living.

The results stated above locate well in the large body of literature on the relationship between assets and microfinance membership (e.g. Khandker, 1998; Johnson and Rogaly, 2002; Henry et al., 2005; Gulli, 2003; GonzalezVega, 2003; Gonzalez de la Rocha, 2006 and Goldberg, 2005). They are also in conformity with results from other empirical studies e.g. Pitt and Khandker (1996 and 1998) in Bangladesh; Zeller, Diagne and Mataya (1998) in Malawi; Nghiem et al., (2007) in Vietnam; Adjei, Arun and Hossain (2009) in Ghana.

We now turn to the analysis of the control variables. First, education is an important proxy for human capital accumulation. Education enhances household productivity by promoting assets accumulation. Kondo et al. (2008) supports this assertion by noting that education is a known determinant of both earning capacity and productivity. Households with members who are educated are expected to have the capability to raise more assets. Table 1 above shows that the level of education is positively related to asset ownership. The coefficient of 0.4888 is statistically significant (with a t-value=3.09). This implies that the more educated individuals tend to accumulate more assets than those with little education. The estimates show that educated respondents exceed uneducated ones by as much as $49 \%$ in asset ownership.

Second, household size (HH size) is also positively related to assets. The HH size variable carries a positive coefficient of 0.5941 which is also significant at $1 \%$ level (t-value=3.05). The sign of the coefficient means that bigger households are more likely to have more assets than smaller ones. The implications are that an increase in household size by $10 \%$ can lead to a $5.9 \%$ increase in assets. This could be because household members contribute labor towards assets accumulation. According to Nghiem et al., (2007) production activities in rural areas are labor intensive therefore bigger households imply higher productivity, ceteris paribus.

Lastly, age has a positive coefficient of 1.2337 and is statistically significant (t-value=4.83) at $10 \%$. This implies that older people have got more opportunities to accumulate more assets. This could be explained by experience, networking (social capital) or maturity. Older people tend to have a higher propensity to save than young people; hence they will have more assets. According to Adjei et al. (2009) older people have got the skill to build assets for their households. 


\section{Conclusion}

The research findings confirm that the rural people have a greater affinity for saving through asset accumulation. The respondents narrated that assets enable them to raise cash for consumption, school fees for their children, purchase of agricultural equipment, among other things. With the help of microfinance programmes, the poor are in a position to identify the three categories of assets thereby enhancing access since they will be informed about the available individual and community assets. Econometric results from the survey data also suggest that microfinance members concentrate more on asset accumulation than other household outcomes. A positive and significant relationship between membership and assets was established.

\section{References}

Adjei, J. K., T. Arun and F. Hossain. (2009). "The Role of Microfinance in Assets-Building and Poverty Reduction: The Case of Sinapi Aba Trust of Ghana". BWPI Working Paper 87. The University of Manchester, Brooks World Poverty Institute. [Online] Available:www.microfinancegateway.org. (September 15, 2010).

Aheeyer, M.M.M. (2006). "Cash Grants and Microfinance in Livelihood Recovery: Experiences from Tsunami-Affected Areas of Sri-Lanka". A Human Policy Group (HPG) Background Paper. United Kingdom: Overseas Development Institute. [Online] Available :www.odi.org.uk/resources/download /3767.pdf (April 27, 2010).

DFID. (1999). "Sustainable Livelihoods Guidance Sheets". [Online] Available: www.nssd.net/pdf/section.pdf (February 01, 2010).

Fay, M., ed. (2005). Relying on Oneself: Assets of the Poor. In The Urban Poor in Latin America. Washington D.C.: World Bank.

Goldberg, N. (2005). "Measuring the Impact of Microfinance: Tacking Stock of What We Know". Grameen Foundations, USA Publication Series. [Online] Available: www.gfusa.org. (July 21, 2008).

Gonzalez-Vega, C. (2003). "Deepening Rural Financial Markets: Macroeconomic, Policy and Political Dimensions", paper for Paving the way for Rural Finance: An international Conference on Best Practices in Rural finance. Washington, D.C, 2-4 June 2003. [Online] Available: http://0-web.ebscohost.com.wam.seals.ac.za/ehost/pdf . (September 11, 2009).

Gonzalez de la Rocha, M. (2006). "Vanishing Assets: Cumulative Disadvantage Among the Urban Poor". The ANNALS of the American Academy of Political and Social Science 2006 606:68. [Online] Available: http://ann.sagepub.com/content/606/1/68. (September 23, 2010).

Gulli, H. (1998). Microfinance and Poverty: Questioning the Conventional Wisdom. Washington D.C.: Inter-American Development Bank.

Henry, C., M. Sharma, C. Lapenu and M. Zeller. (2003). Microfinance Poverty Assessment Tool. Washington DC: CGAP (Consultative Group to Assist the Poor)/ International Bank for Reconstruction and Development (The World Bank).

HSRC. (2002). "Micro-Finance in Rural Communities in Southern Africa: Country \& Pilot Site Case Studies, Policy Issues and Recommendations". Prepared for the Integrated Rural Development Programme of W.K. Kellog Foundation, South Africa. Pretoria. [Online] Available: www.hsrcpress.ac.za. (March 12, 2008).

ICAD. (2001). "HIVIAIDS and Microfinance". Ottawa: Interagency Coalition on AIDS and Development. [Online] Available: www.icad.cisd.com (September 17, 2008)

Johnson, S. and B. Rogaly. (2002). Microfinance and Poverty Reduction. UK: Oxfarm and ActionAid.

Kondo, T., A. Orbeta Jr, C. Dingcong and C. Infantado. (2008). "Impact of Microfinance on Rural Households in the Philippines". IDS Bulletin Volume 39 Number 1 March 2008. Institute of Development Studies.

Morgan, A. and E. Ziglio. (2007). "Revitalising the Evidence for Public Health: Assets Model". Promotion \& Education 2007 14:17. [Online] Available: http://ped.sagepub.com/content/14/2_supp/17. (September 10,2012)

Moser, C. and A.A. Dani , eds. (2008). "Assets, Livelihoods, and Social Policy". New Frontiers of Social Policy. Washington, DC: The World Bank.

Narayan, D., ed. (2002). Empowerment and Poverty Reduction: A Sourcebook. Washington D.C., USA: The World Bank.

Nghiem, H. S., T. Coelli and P. Rao. (2007). "The Welfare Effects of Microfinance in Vietnam: Empirical Results from a Quasi-Experimental Survey". The 51st Annual Conference of the Australian Agriculture and Resources Economics Society 13-16 February 2007. Queenstown, Newzealand: Centre for Efficiency and Productivity Analysis.

Pitt, M. M. and S.R. Khandker. (1996). Household and Intra-household Impact of The Grameen Bank and Similar Targeted Programs in Bangladesh. Washington, D.C.: The World Bank.

Population Council. (2002). "Microfinance and Household Coping with HIVIAIDS in Zimbabwe: An Exploratory Study". Washington D.C.: The Population Council Inc. [Online] Available: www.popocouncil.org/pdfs/horizons/microfinzimbsum.pdf. (October 23, 2007)

Rakodi, C. (2002). "A Livelihoods Approach: Conceptual Issues and Definitions". In Rakdi, C. and T. Lloyd-Jones, (Eds). 2002. Urban Livelihoods: A People Centered Approach to Reducing Poverty. London, Sterling: Earthscan.

Sa-Dhan. (2003). "Sustainable Livelihoods and Microfinance". New Dehli, India: Sa-Dhan. Funded by Ford Foundation. [Online] Available: www.sa-dhan.org. (February 06, 2010).

Sherraden, M. (1991). Assets and the Poor: A New American Welfare Policy. New York: M.E. Shape. Inc.

Smets. (2006). "Small is Beautiful, But Big is often the Practice: Housing Microfinance in Discussion", Habitat International, Vol 30 pages $596-613$.

Solesbury, W. (2003). "Sustainable Livelihoods: A Case Study of the Evolution of DFID Policy". Working Paper 217. London, UK: ODI.

Vermaak, J. (2009). "Social Capital as a Mechanism for Socio-economic Development Amongst Agricultural Producers in Vhembe, Limpopo". AFRICANUS Journal of Development Studies, Volume 39 (1) 2009. South Africa: UNISA Press.

Zhan, M. and M. Sherraden. (2003). "Assets, Expectations, and Children's Educational Achievements in Female-Headed Households". The Social Services Review, Vol 77, No. 2 (June, 2003), pp. 191-211. University of Chicago Press. [Online] Available: http://www.jstor.org/stable/30013140. (September 24, 2010). 